\title{
Teaching NeuroImages: Facial ulceration in stroke
}

\section{An unusual and lesser-known complication described by Wallenberg}

Liau MeiQi May, MRCP, Tan Natalie Soong Hui, Tan Lixian Chris, MBBS, Joy Vijayan, MD, and Nisha Suyien Chandran, MRCP

Neurolog ${ }^{\circledR}$ 2018;90:e1448-e1449. doi:10.1212/WNL.0000000000005332
Correspondence

Dr. Vijayan

joy_vijayan@nuhs.edu.sg

Figure Left facial ulceration and MRI brain demonstrate the lateral medullary infarct

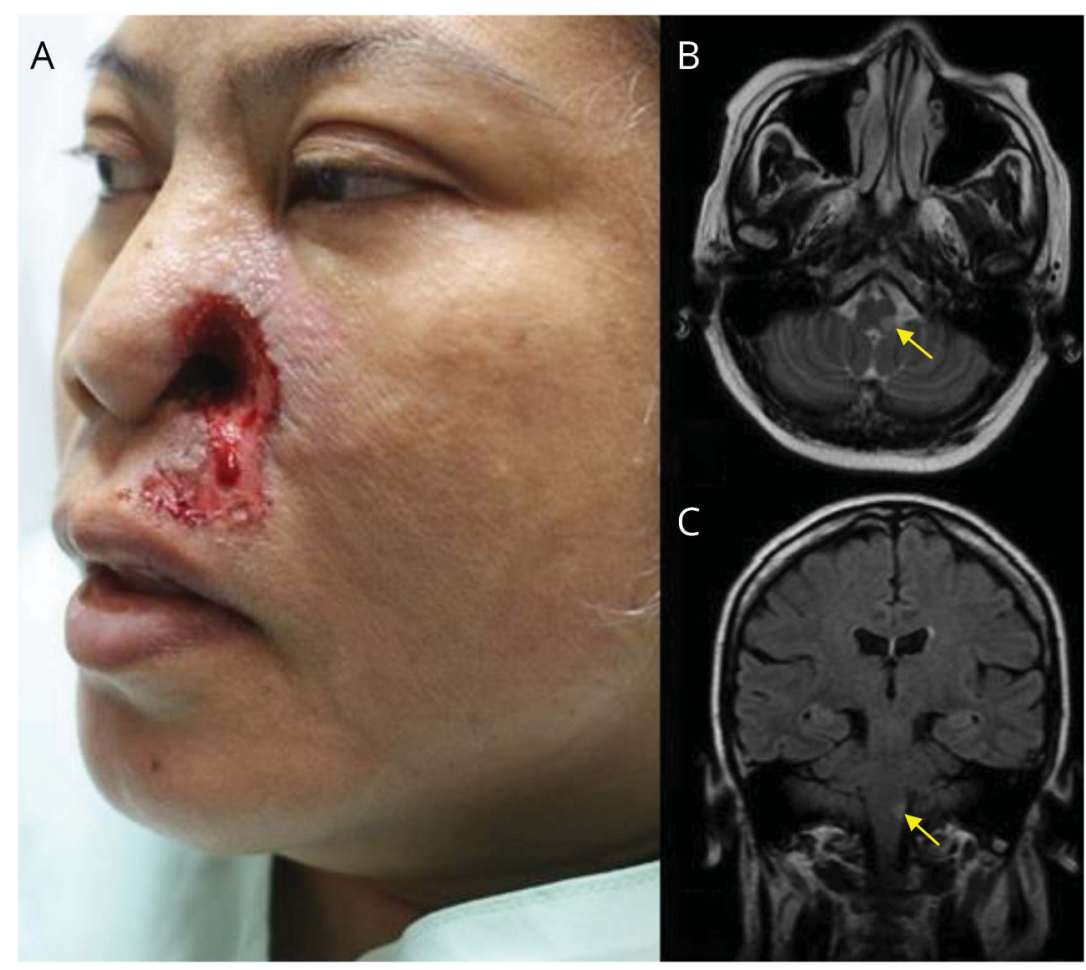

(A) Ulceration and destruction of left nasal ala (B) T2-weighted axial image shows an area of hyperintensity over the left lateral medulla in the distribution of the spinal tract nucleus of the trigeminal nerve. (C) T2-weighted fluid-attenuated inversion recovery coronal image shows the longitudinal extent of the lesion within the medulla.
A 50-year-old woman with a history of lateral medullary stroke 3 years ago presented with a 7month history of persistent itch with constant picking and a nonhealing ulcer on the left side of her face (figure). Examination revealed anesthesia over the V2 distribution of the trigeminal nerve. Trigeminal trophic syndrome is a rare cause of chronic facial ulceration first described by Wallenberg. ${ }^{1}$ It results from damage to the trigeminal ganglion or nerve. Causes include trigeminal nerve ablation, stroke, tumors, herpes, and leprosy. ${ }^{2}$ The ulceration results from selfmutilation due to facial anesthesia and paresthesias.

\section{MORE ONLINE}

\section{$\rightarrow$ Teaching slides}

links.lww.com/WNL/A35

From the Divisions of Dermatology (L.M.M., T.L.C., N.S.C.) and Neurology (J.V.), University Medicine Cluster, National University Hospital, Singapore; and Barts and the London School of Medicine and Dentistry (T.N.S.H.), UK.

Go to Neurology.org/N for full disclosures. Funding information and disclosures deemed relevant by the authors, if any, are provided at the end of the article. 


\section{Author contributions}

L.M.M., T.N.S.H., T.L.C., and N.S.C. performed the initial assessment and investigations of the patient. L.M.M., T.L.C., J.V., and N.S.C. helped in the compilation of the text, literature search, and editing of the manuscript.

\section{Study funding}

No targeted funding reported.

\section{Disclosure}

The authors report no disclosures relevant to the manuscript. Go to Neurology.org/N for full disclosures.

\section{References}

1. Rashid RM, Khachemoune A. Trigeminal trophic syndrome. J Eur Acad Dermatol Venereol 2007;21:725-731.

2. Curtis AR, Oaklander AL, Johnsons A, Yosipovitch G. Trigeminal trophic syndrome from stroke: an under-recognized central itch syndrome. Am J Clin Dermatol 2012;13:125-128. 


\section{Neurology}

\section{Teaching NeuroImages: Facial ulceration in stroke: An unusual and lesser-known complication described by Wallenberg \\ Liau MeiQi May, Tan Natalie Soong Hui, Tan Lixian Chris, et al. \\ Neurology 2018;90; e1448-e1449 \\ DOI 10.1212/WNL.0000000000005332}

\section{This information is current as of April 16, 2018}

\section{Updated Information \& Services}

References

Subspecialty Collections

Permissions \& Licensing

Reprints including high resolution figures, can be found at: http://n.neurology.org/content/90/16/e1448.full

This article cites 2 articles, 0 of which you can access for free at: http://n.neurology.org/content/90/16/e1448.full\#ref-list-1

This article, along with others on similar topics, appears in the following collection(s):

All Cerebrovascular disease/Stroke

http://n.neurology.org/cgi/collection/all_cerebrovascular_disease_strok

Clinical neurology examination

http://n.neurology.org/cgi/collection/clinical_neurology_examination MRI

http://n.neurology.org/cgi/collection/mri

Information about reproducing this article in parts (figures,tables) or in its entirety can be found online at:

http://www.neurology.org/about/about_the_journal\#permissions

Information about ordering reprints can be found online:

http://n.neurology.org/subscribers/advertise

Neurology ${ }^{\circledR}$ is the official journal of the American Academy of Neurology. Published continuously since 1951, it is now a weekly with 48 issues per year. Copyright (O) 2018 American Academy of Neurology. All rights reserved. Print ISSN: 0028-3878. Online ISSN: 1526-632X.

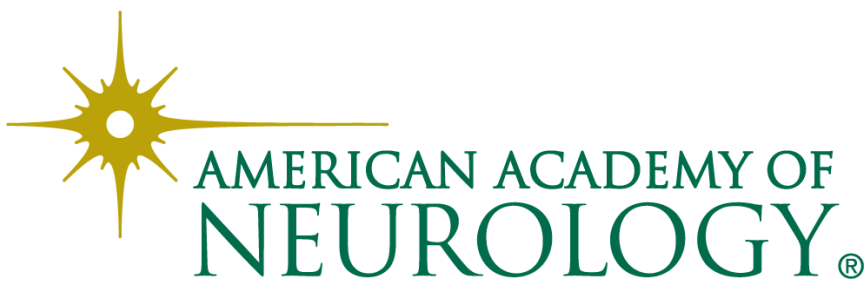

